\title{
Diagnostic value of inflammatory cell infiltrates, tumor stroma percentage and disease-free survival in patients with colorectal cancer
}

\author{
KATARZYNA JAKUBOWSKA ${ }^{1}$, WOJCIECH KISIELEWSKI ${ }^{2}$, LUIZA KAŃCZUGA-KODA ${ }^{1}$, \\ MARIUSZ KODA $^{3}$ and WALDEMAR FAMULSKI ${ }^{1,2}$ \\ ${ }^{1}$ Department of Pathomorphology, Comprehensive Cancer Center; ${ }^{2}$ Department of Medical Pathomorphology, \\ Medical University of Bialystok; ${ }^{3}$ Department of General Pathomorphology, \\ Medical University of Bialystok, Bialystok, Poland
}

Received March 1, 2017; Accepted June 26, 2017

DOI: 10.3892/ol.2017.6639

\begin{abstract}
The anticancer immune defense mechanism involves humoral and cellular responses. The main effector mechanisms of antitumor responses involve the following: the activity of cytotoxic $\mathrm{T}$ cells; the activation of macrophages and neutrophils; the activity of cytokines secreted by T cells; and natural killer cell activity. Selected cell populations are responsible for the stimulation or suppression of the immune system against tumor cells. Therefore, the aim of the present study was to evaluate the location, extent and composition of the cellular inflammatory infiltration of tumors in patients with colorectal cancer (CRC). In addition, the correlation between cellular inflammatory infiltration, and anatomoclinical and histopathological features of patients was evaluated. The study involved 160 patients diagnosed with primary operable $\mathrm{CRC}$. The local inflammatory infiltrate was assessed in the invasive front and center of the tumor using light microscopy with hematoxylin and eosin (H\&E) staining, according to the Klintrup-Makinen criteria, tumor stroma percentage, and Glasgow microenvironment score. The inflammatory infiltrate in the invasive front of the tumor was correlated with gender $(\mathrm{P}=0.018)$, the invasion of blood vessels $(\mathrm{P}=0.020)$ and lymph vessels $(\mathrm{P}=0.038)$, the presence of tumor-infiltrating lymphocytes in the invasive front $(\mathrm{P}=0.033)$ and center $(\mathrm{P}<0.001)$ of the tumor, fibrosis $(\mathrm{P}<0.001)$, and the degree of desmoplasmic stroma $(\mathrm{P}=0.004)$. In contrast, inflammatory infiltration in the center of the tumor was associated with the tumor node metastasis stage $(\mathrm{P}=0.012)$, Dukes' stage $(\mathrm{P}=0.009)$, primary
\end{abstract}

Correspondence to: Dr Katarzyna Jakubowska, Department of Pathomorphology, Comprehensive Cancer Center, 12 Ogrodowa Street, 15-027 Bialystok, Poland

E-mail: kathian@wp.pl

Key words: inflammatory cell infiltration, colorectal cancer, TSP, immune response tumor stage $(\mathrm{P}=0.036)$, lymph node status $(\mathrm{P}=0.005)$, number of lymph nodes $(\mathrm{P}=0.006)$, invasion of lymph node pouches $(\mathrm{P}=0.021)$, size of lymph node metastasis $(\mathrm{P}=0.025)$ and the degree of desmoplasmic stroma $(\mathrm{P}=0.002)$. The low-group, who demonstrated an absent or weak inflammatory cell infiltrate in the invasive front of the tumor, had a statistically significant shorter disease-free survival (DFS) time ( $\mathrm{P}=0.004)$. Inflammatory cell infiltrate in the invasive front was identified as an independent predictive factor in CRC $(\mathrm{P}=0.041)$. In conclusion, the degree of inflammatory cell infiltration in the invasive front of the primary tumor significantly affects various variables that determine disease progression and DFS rates of patients with CRC. Furthermore, the routine histopathological assessment of this parameter in tissue stained with H\&E may have potential prognostic value.

\section{Introduction}

Colorectal cancer (CRC) is the second-leading death-related malignant tumor in Poland in both sexes (1). The prognosis of patients is performed by staging of primary tumor and the involvement of metastases in the lymph nodes and distant organs by standard classification of the Union for International Cancer Control/American Joint Committee on Cancer (UICC/AJCC) classification based upon the tumor-node-metastasis (TNM) (2). However, recent reports in the literature indicated that a considerable heterogeneity of the primary tumor of colon cancer requires a more detailed qualitative analysis, all of its components such as inflammatory response and connective tissue stroma $(3,4)$.

Vascular connective tissue is an important part of the tumor which forms its framework. It transfers the nutrients into proliferating, neoplastic cells. Due to certain elements, the stromal tumor retains its integrity and has the ability to increase as a destructive parasite on the host organism. The production of biologically active compounds can be done during the interaction between the structural elements of the stroma such as inflammatory cell infiltration and cancer cells (5). It has been shown that the tumor stroma including fibroblasts, endothelial cells, and inflammatory 
cells play an important role in promoting the progression of the disease $(6,7)$. Desmoplasic stromal reaction (DR) is a poor prognostic factor for patients with CRC. Moreover, the appearance of liver metastases is accompanied by a large DR with SMA-positive myofibroblasts $(8,9)$. Furthermore, Conti et al (10) found that DR stimulates the growth of primary tumor and decreases the chemosensitivity of CRC metastasis in the liver.

Tumor stroma, as myofibroblasts, may affect the organization of the inflammatory response. Dysregulation of the immune response is already visible in the early stages of precancerous adenoma-colorectal carcinoma sequence in which decrease in the activity of Th1 cells is observed (11). By contrast, the development of CRC on the basis of inflammatory bowel disease is characterized by the stimulation of immune responses by $\mathrm{CD}^{+} \mathrm{T}$-cells (12). Recent reports showed that both the inflammatory cell infiltration and tumor stroma affect the development and progression of CRC (13). Therefore, the aim of our study was to assess inflammatory cell infiltrate in the invasive front and in the center of primary tumor mass, and tumor stroma percentage (TSP) in correlation with anatomoclinical features of CRC patients.

\section{Materials and methods}

Patients. The study group consisted of 160 patients diagnosed with colorectal carcinoma (female, 56, male, 88) and operated on at the Department of Oncological Surgery, in the Comprehensive Cancer Center of Bialystok, during years 2014-2016. The data collection procedures and statistical analysis were designed before the collection of study material had started. The mean age was 67.5 years, including 40 patients under 60 years of age and 120 patients over 6 decades of life. Mostly, patients were complained about abdominal ache, anemia and bleeding from rectum. Family's medical history of malignant neoplasms was noted in 16 out of 160 cases. Patients were taking medicine against hypertension, type II diabetes, osteoarthritis and coronary heart disease in most of cases. We excluded patients with clinical evidence of active infection and/or chronic inflammatory condition. Colonoscopy examination was performed in 62 cases that confirmed the presence of cancerous infiltrate in the intestinal wall. Macroscopically, cancerous infiltrate was limited to the gut wall in 69 cases, exceeded the wall focally in 17 cases and continuously in 74 cases.

All patients, during routine diagnostics, underwent a basic diagnostic laboratory examination, ECG, spirometry, arterial blood gasometric study and X-ray and computerized tomography of the chest. The clinical efficiency was performed by 5-point scale of Zubroda (WHO) (14). The clinical staging of CRC was evaluated according to TNM classification (2). Patients diagnosed with neoplasms in rectum received preoperative therapy $(\mathrm{N}=53)$. Patients received radiotherapy $(\mathrm{N}=39)$, chemotherapy $(\mathrm{N}=7)$ and radio-chemotherapy $(\mathrm{N}=7)$. They took a dose of $25 \mathrm{~Gy}$ in fractions of $5 \mathrm{~Gy}$ during one week in the pelvic area. Patients with tumors situated on other localization had received neither inflammatory nor immunosuppressive therapy. The response to preoperative therapy was estimated according to the Response Evaluation Criteria in Solid Tumors (RECIST) criteria (15).
The study was performed in conformity with the Declaration of Helsinki for Human Experimentation and the protocol was approved by the Bioethics Committee of the Medical University of Bialystok (no. R-I-002/353/2016). Written informed consent was obtained from all participants.

Histopathological examination of CRC tumor. Sections, $4 \mu \mathrm{m}$-thick, were cut from paraffin blocks and stained with hematoxylin and eosin (H\&E) (cat no. 468802128; POCH S.A., Poland). The routine histopathological assessment of the sections referred to type of tumor growth, tumor size, histological type and percentage of the mucinous component, grade of malignancy, pTNM and Duke stages. We also analyzed venous, lymphatic and perineural invasions, characteristic features of lymph node invasion such as number of resected and invaded lymph nodes, the presence of micro- and macrometastases, invasion of the pouch lymph node; presence of the distant metastases and their size in millimetre. We also assessed the presence of deposits, their number and size in millimetre (16). We analyzed tumor budding according to Morodomi et al (17). The extent of necrosis and fibrosis in the central tumor was evaluated according to Richards et al (18) and graded as 'absent' (none), 'focal' ( $<10 \%$ of tumor area), 'moderate' (10-30\%) or 'extensive' (>30\%). Crohn's-like aggregates of lymphocyte (CRL) were performed in the basis of Väyrynen's et al criteria (19). Histological categorization of fibrotic cancer stroma was performed based on classification described by the Ueno et al (20).

Examination of inflammatory cell infiltration, TSP and Glasgow microenvironment score (GMS). The inflammatory cell infiltrates were assessed according to Klintrup-Makinen (K-M) (21) criteria and performed by two independent pathologists who have been blinded to the clinical information. Briefly, inflammatory reaction in the invasive margin and centre of tumor were scored on 4-point scale where score ' 0 ' defined no increase in inflammatory cell infiltrate; score ' 1 ' defined a mild or patchy increase; score ' 2 ' denoted a prominent inflammatory reaction with some evidence of cancer cell destruction and score ' 3 ' denoted florid 'cup-like' inflammatory infiltrate. The inflammatory cell infiltrate were classified into low-group (score 0-1) and high-group (score 2-3). Invasive front of tumor was defined as the most progressed few cancer cells localized on the advanced edge of tumor. We assessed the TSP according to criteria described by Huijbers et al (22). TSP ratio was dived into two groups: 'high TSP group' (>50\%) and 'low TSP group' ( $\leq 50 \%)$. We also analyzed the GMS (4) based on the K-M grade and TSP. Patients were characterized as having, i) good prognosis (high score of K-M and any TSP score); ii) intermediate prognosis (low K-M score and low TSP score) and iii) poor prognosis (low K-M score and high TSP score).

Follow-up. Patients were followed-up during last 2-2.5 years. They were monitored by the measurement of carcinoembryonic antigen (CEA) and CA19-9 levels, physical examination, colonoscopy or/and radiological imaging including computerized tomography of the chest, abdomen, and pelvis, bone scan, and positron emission tomography scans. Local and distant recurrences were defined as pathologic evident of the spread 


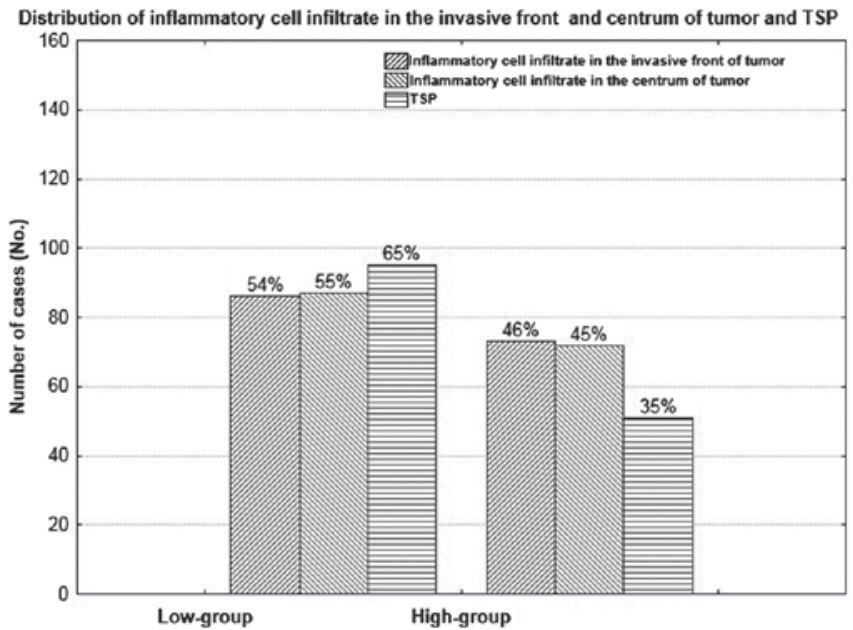

Figure 1. Distribution of inflammatory cell infiltration in the invasive front, in centre of primary tumor mass and TSP in low and high group of patients with colorectal cancer. TSP, tumor stroma percentage.

of tumors in the region of the anastomosis (local recurrence) or/and present outside of the primary tumor at other sites such as liver, lungs, bones, brain (distant recurrence) and confirmed by mentioned above techniques.

Statistical analysis. Statistical analysis was conducted using the STATISTICA 10.0 program (StatSoft, Kracow, Poland). Mann-Whitney U-test was use to compare the groups. Correlations between the parameters were calculated by the Spearman's correlation coefficient tests. Disease-free survival (DFS) was calculated from the date of diagnosis to the date of disease progression (local or distant relapse). DFS were estimated using Kaplan Meier method and the survival curves were compared using log-rank tests. Multivariate Cox proportional hazards models were used to estimate hazard ratios. A P-value of $<0.05$ was considered statistically significant.

\section{Results}

Distribution of inflammatory cell infiltrates and characteristics of TSP and GMS in CRC. The inflammatory cell infiltrate
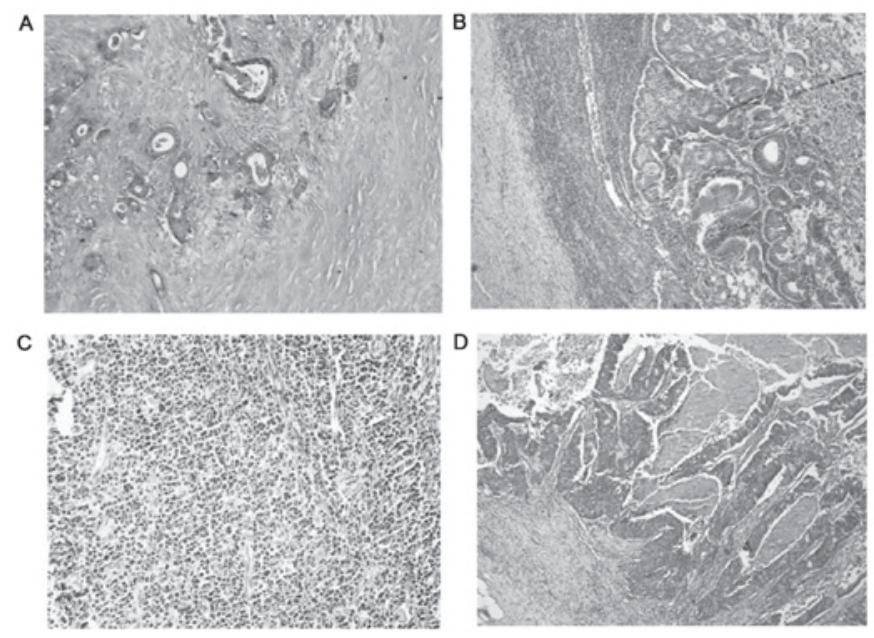

Figure 2. Examination of inflammatory cell infiltrate in colorectal cancer tissue. (A) Low-group: Lack of inflammatory response in the invasive front of tumor, (B and C) High-group: Strong infiltration of mononuclear cells in the tumor margin, (D) low-group: Weak inflammatory infiltrate in the centrum of the main mass associated with necrosis (H\&E stain). H\&E, hematoxylin and eosin.

in the invasive front of tumor was low in 86 (54\%) and high in $73(46 \%)$ of cases, and was similar to those observed in the centrum of tumor mass. Low-group of TSP was present in 95 (65\%) cases in comparison with 51 (35\%) cases observed in high TSP group (Figs. 1-3). Examined group of parameters did not differ significantly $(\mathrm{P}=0.059 ; \mathrm{P}=0.065 ; \mathrm{P}=0.910)$. Patient prognosis, based on GMS was: good in 55, intermediate in 49 and poor in 56 cases.

Inflammatory cell infiltrates in the invasive front of CRC and its correlation with anatomoclinical variables. Inflammatory cell infiltrate in the invasive front was found to correlate negatively with female $(\mathrm{P}=0.018, \mathrm{R}=-0.197)$, venous and lymphatic invasion $(\mathrm{P}=0.020, \mathrm{R}=-0.193 ; \mathrm{P}=0.038$, $\mathrm{R}=-0.173$, respectively), invasion of lymph node pouch $(\mathrm{P}=0.020, \mathrm{R}=-0.212)$, TSP $(\mathrm{P}=0.015, \mathrm{R}=-0.212)$ and the stage of fibrosis $(\mathrm{P}<0.000, \mathrm{R}=-0.293)$. The increase of the inflammatory cell infiltrate in the invasive front of tumor was
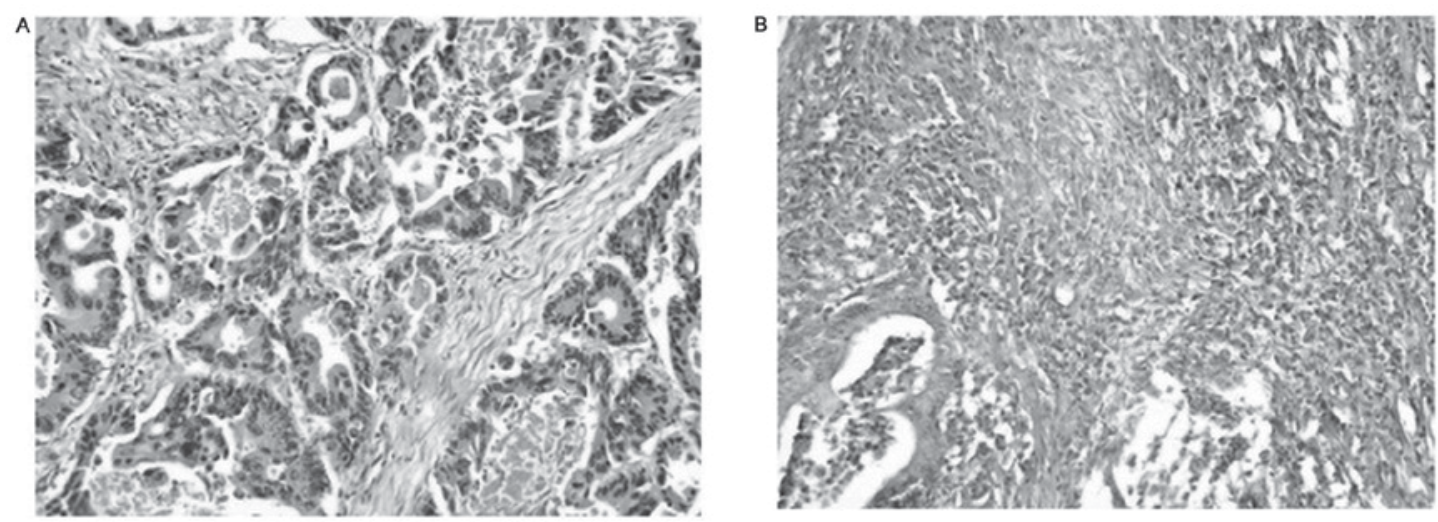

Figure 3. Assessment of TSP based on H\&E staining. (A) Low-TSP group presents less than 50\% tumor stroma with strong inflammatory cell infiltrate in the centrum of primary tumor mass. (B) Sections with high-TSP group are characterized by undifferentiated fibrotic stroma and lack of inflammatory cells in most of cases. TSP, tumor stroma percentage; H\&E, hematoxylin and eosin. 
Table I. Correlation between inflammatory cell infiltration in the invasive front and main mass of primary tumor and anatomoclinical variables of colorectal cancer.

\begin{tabular}{|c|c|c|c|c|c|}
\hline \multirow[b]{2}{*}{ Variables } & \multirow{2}{*}{$\begin{array}{c}\mathrm{N} \\
160\end{array}$} & \multicolumn{2}{|c|}{$\begin{array}{l}\text { Inflammatory } \\
\text { cell infiltration } \\
\text { in the invasive } \\
\text { front of tumor }\end{array}$} & \multicolumn{2}{|c|}{$\begin{array}{l}\text { Inflammatory } \\
\text { cell infiltration } \\
\text { in the center } \\
\text { of tumor mass }\end{array}$} \\
\hline & & $\mathrm{R}$ & P-value & $\mathrm{R}$ & P-value \\
\hline \multicolumn{6}{|l|}{ Age } \\
\hline$<60$ & 40 & NS & NS & NS & NS \\
\hline$>60$ & 120 & & & & \\
\hline \multicolumn{6}{|l|}{ Gender } \\
\hline Female & 64 & -0.197 & 0.018 & NS & NS \\
\hline Male & 96 & & & & \\
\hline \multicolumn{6}{|l|}{ Localization } \\
\hline Right-side & 20 & NS & NS & NS & NS \\
\hline Transverse & 14 & & & & \\
\hline Left-side & 15 & & & & \\
\hline Sigmoid & 29 & & & & \\
\hline Rectum & 82 & & & & \\
\hline \multicolumn{6}{|l|}{ Tumor growth } \\
\hline Expanding & 133 & NS & NS & NS & NS \\
\hline Infiltrate & 27 & & & & \\
\hline \multicolumn{6}{|c|}{ Tumor size, $\mathrm{cm}$} \\
\hline$<2.5$ & 27 & NS & NS & NS & NS \\
\hline $2.5-5.0$ & 106 & & & & \\
\hline$>5.0$ & 27 & & & & \\
\hline \multicolumn{6}{|l|}{ TNM stage } \\
\hline 1 & 42 & NS & NS & -0.200 & 0.012 \\
\hline 2 & 31 & & & & \\
\hline 3 & 69 & & & & \\
\hline 4 & 18 & & & & \\
\hline \multicolumn{6}{|l|}{ Duke stage } \\
\hline A & 39 & NS & NS & -0.218 & 0.009 \\
\hline $\mathrm{B}$ & 35 & & & & \\
\hline $\mathrm{C}$ & 69 & & & & \\
\hline $\mathrm{D}$ & 17 & & & & \\
\hline \multicolumn{6}{|c|}{ Adenocarcinoma type } \\
\hline Partim muc & 30 & NS & NS & NS & NS \\
\hline Nonmuc & 130 & & & & \\
\hline \multicolumn{6}{|c|}{ Percentage of mucinous component } \\
\hline $10-30 \%$ & 15 & NS & NS & NS & NS \\
\hline $30-50 \%$ & 15 & & & & \\
\hline \multicolumn{6}{|c|}{ Grade of malignancies } \\
\hline 2 & 148 & NS & NS & NS & NS \\
\hline 3 & 12 & & & & \\
\hline \multicolumn{6}{|c|}{ Preoperative treatment } \\
\hline Yes & 53 & NS & NS & NS & NS \\
\hline No & 107 & & & & \\
\hline \multicolumn{6}{|c|}{ Treatment response } \\
\hline $\mathrm{SD}$ & 26 & NS & NS & NS & NS \\
\hline PR & 27 & & & & \\
\hline
\end{tabular}


Table I. Continued.

\begin{tabular}{|c|c|c|c|c|c|}
\hline \multirow[b]{2}{*}{ Variables } & \multirow{2}{*}{$\begin{array}{c}\mathrm{N} \\
160\end{array}$} & \multicolumn{2}{|c|}{$\begin{array}{l}\text { Inflammatory } \\
\text { cell infiltration } \\
\text { in the invasive } \\
\text { front of tumor }\end{array}$} & \multicolumn{2}{|c|}{$\begin{array}{l}\text { Inflammatory } \\
\text { cell infiltration } \\
\text { in the center } \\
\text { of tumor mass }\end{array}$} \\
\hline & & $\mathrm{R}$ & P-value & $\mathrm{R}$ & P-value \\
\hline \multicolumn{6}{|l|}{ pT stage } \\
\hline 1 & 3 & NS & NS & -0.175 & 0.036 \\
\hline 2 & 62 & & & & \\
\hline 3 & 91 & & & & \\
\hline 4 & 4 & & & & \\
\hline
\end{tabular}

Bold numbers indicate values considered to be statistically significant. Spearman's correlation coefficient test; NS, not statistically significant.

Table II. Correlation between inflammatory cell infiltration in the invasive front and main mass of primary tumor and morphological variables of colorectal cancer.

\begin{tabular}{|c|c|c|c|c|c|}
\hline \multirow[b]{2}{*}{ Variables } & \multirow{2}{*}{$\begin{array}{c}\mathrm{N} \\
160\end{array}$} & \multicolumn{2}{|c|}{$\begin{array}{l}\text { Inflammatory } \\
\text { cell infiltration } \\
\text { in the invasive } \\
\text { front of tumor }\end{array}$} & \multicolumn{2}{|c|}{$\begin{array}{l}\text { Inflammatory } \\
\text { cell infiltration in } \\
\text { the center } \\
\text { of tumor mass }\end{array}$} \\
\hline & & $\mathrm{R}$ & P-value & $\mathrm{R}$ & $\mathrm{P}$-value \\
\hline \multicolumn{6}{|c|}{ Venous invasion } \\
\hline Absent & 113 & -0.193 & 0.020 & NS & NS \\
\hline Present & 46 & & & & \\
\hline \multicolumn{6}{|c|}{ Lymphatic invasion } \\
\hline Absent & 121 & -0.173 & 0.038 & NS & NS \\
\hline Present & 38 & & & & \\
\hline \multicolumn{6}{|c|}{ Perineural invasion } \\
\hline Absent & 143 & NS & NS & -0.191 & 0.022 \\
\hline Present & 17 & & & & \\
\hline \multicolumn{6}{|c|}{ No. of removed lymph nodes } \\
\hline$<5$ & 13 & NS & NS & NS & NS \\
\hline $5-10$ & 29 & & & & \\
\hline$>10$ & 116 & & & & \\
\hline \multicolumn{6}{|c|}{ Lymph node metastasis } \\
\hline Absent & 81 & NS & NS & -0.230 & 0.005 \\
\hline Present & 79 & & & & \\
\hline \multicolumn{6}{|c|}{ Type of lymph node metastasis } \\
\hline Micro & 27 & NS & NS & -0.198 & 0.017 \\
\hline Macro & 52 & & & & \\
\hline \multicolumn{6}{|c|}{ Number of metastatic lymph nodes } \\
\hline$<5$ & 49 & NS & NS & -0.323 & 0.012 \\
\hline$>5$ & 26 & & & & \\
\hline \multicolumn{6}{|c|}{ Lymph node pouch invasion } \\
\hline Absent & 11 & -0.212 & 0.010 & -0.191 & 0.021 \\
\hline Present & 68 & & & & \\
\hline \multicolumn{6}{|c|}{ Distant metastasis } \\
\hline Absent & 143 & NS & NS & NS & NS \\
\hline Present & 17 & & & & \\
\hline
\end{tabular}


Table II. Continued.

\begin{tabular}{|c|c|c|c|c|c|}
\hline \multirow[b]{2}{*}{ Variables } & \multirow{2}{*}{$\begin{array}{c}\mathrm{N} \\
160\end{array}$} & \multicolumn{2}{|c|}{$\begin{array}{l}\text { Inflammatory } \\
\text { cell infiltration } \\
\text { in the invasive } \\
\text { front of tumor }\end{array}$} & \multicolumn{2}{|c|}{$\begin{array}{l}\text { Inflammatory } \\
\text { cell infiltration in } \\
\text { the center } \\
\text { of tumor mass }\end{array}$} \\
\hline & & $\mathrm{R}$ & P-value & $\mathrm{R}$ & P-value \\
\hline \multicolumn{6}{|c|}{ Distant metastasis size $(\mathrm{mm})$} \\
\hline$<10$ & 11 & NS & NS & NS & NS \\
\hline$>10$ & 6 & & & & \\
\hline \multicolumn{6}{|l|}{ Tumor deposits } \\
\hline Absent & 133 & NS & NS & NS & NS \\
\hline Present & 27 & & & & \\
\hline \multicolumn{6}{|c|}{ Size of tumor deposits (mm) } \\
\hline$<2.5$ & 10 & NS & NS & NS & NS \\
\hline$>2.5$ & 17 & & & & \\
\hline \multicolumn{6}{|l|}{$\operatorname{TSP}(\%)$} \\
\hline$<50$ & 94 & -0.212 & 0.015 & NS & NS \\
\hline$>50$ & 66 & & & & \\
\hline \multicolumn{6}{|l|}{ Tumor budding } \\
\hline Absent & 94 & NS & NS & NS & NS \\
\hline Present & 66 & & & & \\
\hline \multicolumn{6}{|c|}{ Crohn's-like aggregates of lymphocyte } \\
\hline Absent & 113 & NS & NS & 0.195 & 0.019 \\
\hline Present & 42 & & & & \\
\hline \multicolumn{6}{|l|}{ Necrosis } \\
\hline Absent & 45 & NS & NS & NS & NS \\
\hline Focal & 61 & & & & \\
\hline Moderate & 36 & & & & \\
\hline Extensive & 18 & & & & \\
\hline \multicolumn{6}{|l|}{ Fibrosis } \\
\hline Absent & 11 & -0.293 & 0.000 & NS & NS \\
\hline Focal & 72 & & & & \\
\hline Moderate & 43 & & & & \\
\hline Extensive & 34 & & & & \\
\hline \multicolumn{6}{|c|}{ Maturation of fibrotic stroma } \\
\hline Immature & 12 & 0.238 & 0.004 & 0.256 & 0.002 \\
\hline Intermediate & 91 & & & & \\
\hline Mature & 57 & & & & \\
\hline
\end{tabular}

Bold numbers indicate values considered to be statistically significant. Spearman's correlation coefficient test; NS, not statistically significant; TSP, tumor stroma percentage.

associated with increase of stromal maturation $(\mathrm{P}=0.004$, $\mathrm{R}=0.238$ ) (Tables I and II).

Inflammatory cell infiltrates in the centrum of the mass of $C R C$ in correlation with anatomoclinical variables. Inflammatory cell infiltrate in the centrum of the tumor mass was associated with parameter response for disease progression. Inflammatory cell infiltrate in this localization in tumor was negatively correlated with TNM and Duke stage $(\mathrm{P}=0.012$,
$\mathrm{R}=-0.200 ; \mathrm{P}=0.009, \mathrm{R}=-0.218)$, $\mathrm{pT}$ stage $(\mathrm{P}=0.036, \mathrm{R}=-0.175)$, invasion of perineural structures $(\mathrm{P}=0.022, \mathrm{R}=-0.191)$, lymph node status $(\mathrm{P}=0.005, \mathrm{R}=-0.230)$, type of lymph nodes $(\mathrm{P}=0.017, \mathrm{R}=-0.198)$, number of metastatic lymph nodes $(\mathrm{P}=0.012, \mathrm{R}=-0.323)$ and the invasion of lymph node pouches $(\mathrm{P}=0.021, \mathrm{R}=-0.151)$. Cronh's-like aggregates of lymphocyte and maturation of fibrotic stroma were positively associated with the increase of inflammatory cell infiltrate in the centre of tumor mass $(\mathrm{P}=0.019, \mathrm{R}=0195 ; \mathrm{P}=0.002$, 
Table III. Prognostic factors in patients with CRC.

\begin{tabular}{|c|c|c|c|}
\hline Variables & $\begin{array}{c}\text { Univariate } \\
\text { p-value }\end{array}$ & $\begin{array}{c}\text { Multivariate } \\
\text { p-value }\end{array}$ & HR $(95 \% \mathrm{CI})$ \\
\hline Age $(\leq 60$ vs. $\geq 60)$ & 0.059 & - & $1.21(0.36-1.53)$ \\
\hline Gender (female vs. male) & 0.597 & - & $2.19(1.88-3.53)$ \\
\hline Tumor growth (expanding vs. infiltrate) & 0.288 & - & $1.68(1.06-1.90)$ \\
\hline Tumor size $(<2.5$ vs. $2.5-5$ vs. $>5 \mathrm{~cm})$ & 0.349 & - & $0.77(0.27-.87)$ \\
\hline TNM stage (I-IV) & 0.258 & - & $0.85(0.13-1.27)$ \\
\hline Duke stage (A-D) & 0.628 & - & $1.22(0.42-1.45)$ \\
\hline \multicolumn{4}{|l|}{ Adenocarcinoma type } \\
\hline (nonmuc. vs. partim mucin) & 0.359 & - & $0.62(0.51-0.84)$ \\
\hline Grade of malignancies (2 vs. 3 ) & 0.220 & - & $0.39(0.23-1.49)$ \\
\hline Preoperative treatment (yes vs. no) & 0.048 & 0.784 & $1.05(0.75-1.52)$ \\
\hline pT stage $(1-4)$ & 0.674 & - & $1.00(0.17-.1 .2)$ \\
\hline Venous invasion (yes vs. no) & 0.109 & - & $2.72(1.62-2.93)$ \\
\hline Lymphatic invasion (yes vs. no) & 0.149 & - & $0.36(0.23-2.08)$ \\
\hline Perineural invasion (yes vs. no) & 0.121 & - & $2.30(1.54-2.40)$ \\
\hline No. of removed lymph nodes (<5 vs. $5-10$ vs. $<10)$ & 0.816 & - & $0.94(0.05-1.42)$ \\
\hline Lymph node metastasis (yes vs. no) & 0.079 & - & $1.47(0.92-3.07)$ \\
\hline Type of lymph node metastasis (micro vs. macro) & 0.039 & 0.103 & $1.21(0.19-2.65)$ \\
\hline Number of metastatic lymph nodes ( $<5$ vs. $>5)$ & 0.951 & - & $0.96(0.61-1.22)$ \\
\hline Lymph node pouch invasion (yes vs. no) & 0.374 & - & $0.55(0.45-0.78)$ \\
\hline Distant metastasis (yes vs. no) & 0.702 & - & $0.96(0.14-1.23)$ \\
\hline Distant metastasis size $<10$ vs. $>10 \mathrm{~mm}$ & 0.637 & - & $1.05(0.22-1.24)$ \\
\hline Tumor deposits (yes vs. no) & 0.099 & - & $0.53(0.37-2.72)$ \\
\hline Tumor budding (yes vs. no) & 0.267 & - & $0.65(0.47-0.77)$ \\
\hline Number of tumor budding & 0.025 & 0.059 & $1.05(0.57-3.53)$ \\
\hline Fibrosis (low vs. high) & 0.524 & - & $1.25(0.40-1.48)$ \\
\hline Necrosis (low vs. high) & 0.615 & - & $0.84(0.25-1.12)$ \\
\hline Maturation of tumor stroma (low vs. high) & 0.471 & - & $0.83(0.51-1.26)$ \\
\hline Inflammatory cell infiltrate in the invasive front of tumor (present vs. absent) & 0.037 & 0.041 & $0.50(0.33-4.14)$ \\
\hline Inflammatory cell infiltrate in center of tumor (present vs. absent) & 0.733 & - & $0.92(0.23-1.56)$ \\
\hline TSP (low vs. high) & 0.054 & - & $0.46(0.35-4.66$ \\
\hline
\end{tabular}

Bold numbers indicate values considered to be statistically significant.

$\mathrm{R}=0.256$, respectively). Results of correlation are showed in Tables I and II.

Inflammatory cell infiltrates TSP and GMS in CRC DFS. Low-group who showed an absent or weak inflammatory cell infiltrate in the invasive front of the tumor had statistically significant shorter DFS ( $\mathrm{P}=0.004)$. The 1-year and 2-year DFS of the low group with inflammatory cell infiltrate in the invasive front of the tumor were 64 and $51 \%$, whereas patients with high inflammatory cell infiltrate had 1- and 2-year DFS of 83 and $80 \%$. DFS did not differ in the inflammatory cell infiltrate in the centrum of the tumor mass, TSP and GMS $(\mathrm{P}=0.252$, $\mathrm{P}=0.447, \mathrm{P}=0.902, \mathrm{P}=0.418$ ) (Fig. 4). Low TSP group had 1-year DFS of $76 \%$ and 2-year DFS of $56 \%$, whereas patients with high TSP group had 1-year DFS of 78\% and 2-year DFS of $35 \%$. Univariate analysis showed that preoperative treatment $(\mathrm{P}=0.048)$, type of lymph nodes $(\mathrm{P}=0.039)$, number of tumor deposits $(\mathrm{P}=0.025)$ have prognostic values. Moreover, the multivariate Cox-analysis proved that inflammatory cell infiltrate in the invasive front was an independent predictive factors in CRC ( $\mathrm{P}=0.041)$ (Table III).

\section{Discussion}

Inflammatory infiltration located in both the invasive front and in the center of the primary tumor may play a significant role in the development of malignant tumors. In our study, we noted the lack of weak inflammatory infiltration in the invasive front and in center of the tumor in $50 \%$ of cases comparable to a medium or large infiltration in both locations (45-46\%). Richards et al (18) reported a low-grade inflammatory cell infiltrate in $48 \%$ and high-grade inflammatory cell infiltrate in $52 \%$ cases in peritumoral stroma. We also noted low-TSP in $65 \%$ of cases and high-TSP in $35 \%$ of cases. Also, 

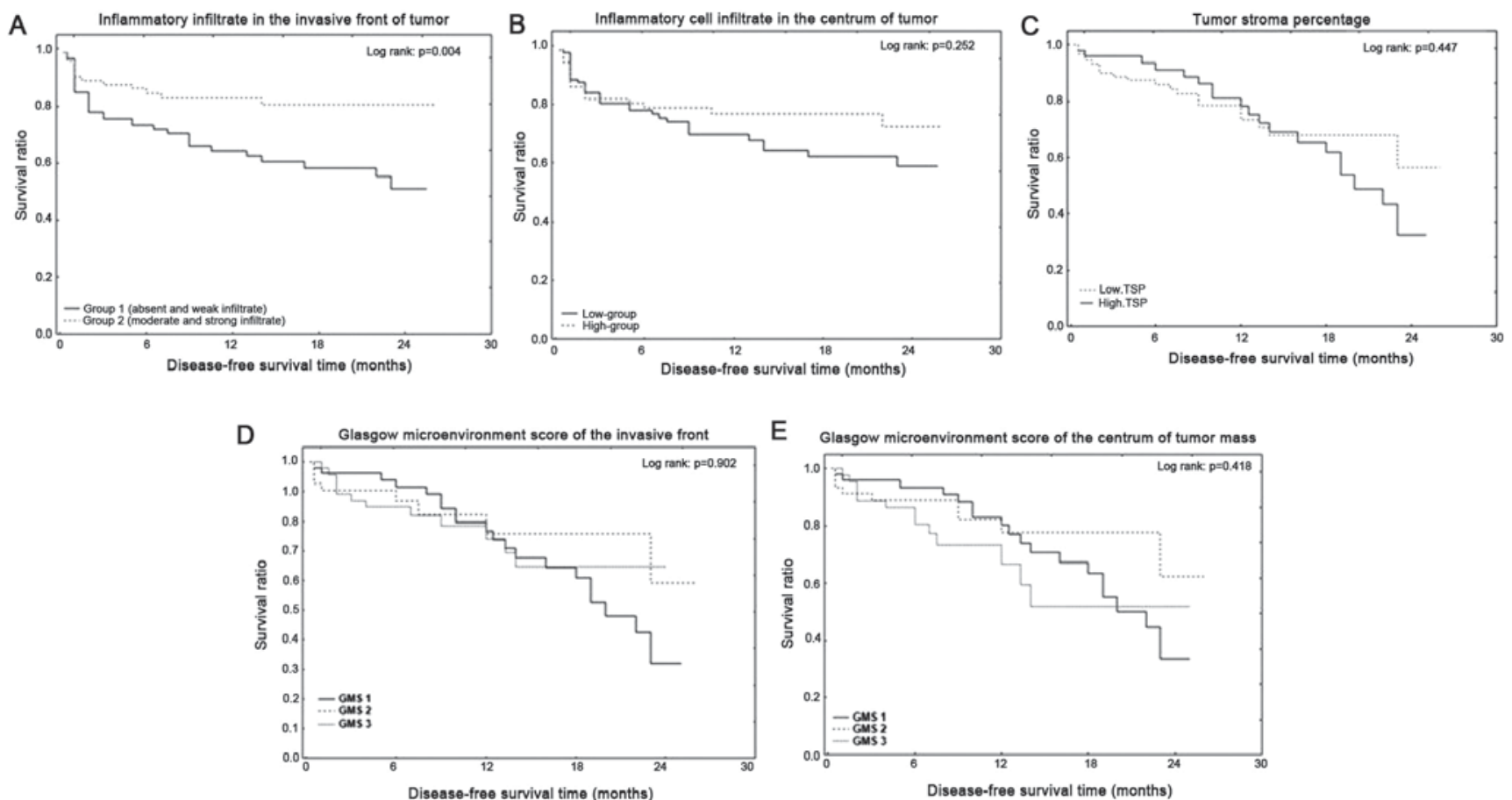

Figure 4. Postoperative disease-free survival of patients with colorectal cancer. Kaplan Meier curves of inflammatory cell infiltration in the invasive front (A) and in the main mass of primary tumor (B), tumor stroma percentage (C), Glasgow Microenvironment Score of the invasive front (D) and centre of primary tumor (E).

Park et al (23) observed that the TSP was low in $75 \%$ of cases and high in $25 \%$ of cases. These observations confirmed that the presence of inflammatory infiltrate may be different in the cases of CRC patients. Probably, it is determined by the activity of the immune system, the speed of its reorganization during detection of tumor-associated antigen (TAA), the preoperative treatment modulating pathway of inflammatory response or the ability of tumor cells to produce specific antigens directly blocking immunocompetitive cells.

Inhibition or impartation of the inflammatory response allows malignant tumor cells to invade into the tissue. We confirmed such observation by correlations, in which together with the decrease in the inflammatory response increased tumor stage, TNM, and Duke's stage, including the primary tumor stage (pT), the presence of tumor cell emboli in blood and the lymphatic vessels, in perineutral spaces. Moreover, the degree of inflammatory infiltration was negatively correlated with the the presence of lymph node metastasis, its size, exceeding the lymph pouches and infiltration structures near to metastatic lymph nodes. Our results are consistent with the observations of Galon et al (12), Menon et al (24) and Väyrynen et al (25). They confirmed that patients with high TNM stage linked with presence of distant metastases were correlated with lower immune response. Moreover, authors showed that peritumoral inflammatory cell infiltrate was higher in advanced stage than in intratumoral densities. Also, Richards et al $(18,26)$ demonstrated the presence of the relationship between the inflammatory cell infiltrate and $\mathrm{pT}$ status, positive lymph node status, TNM stage, venous invasion, necrosis and character of tumor growth.

Several studies confirmed an association between tumor inflammatory infiltrates and survival of patients with malignant neoplasms (27-29). In our study, we showed that patients with low inflammatory cell infiltrate located in the invasive front had a shorter DFS), which was $64 \%$ after 12 months and $51 \%$ after 24 months after the surgery. Mei et al (13) showed that a high level of $\mathrm{CD}^{+}$cells in the invasive front was associated with good overall survival (OS) and DFS. Moreover, a high level of $\mathrm{CD}^{+}$cells, but not $\mathrm{CD} 3^{+}$ or $\mathrm{FOXP}^{+}$was correlated with better prognosis and longer OS. Also, Väyrynen et al (25) confirmed the relationship between the degree of inflammatory infiltration assessed in the basis of $\mathrm{M}-\mathrm{K}$ criteria and the occurrence of relapse in patients with CRC. We also analyzed the relationship between TSP, GMS and DFS of patients with CRC. Patients with low-TSP had 1-year DFS of 76\% whereas the 2-year DFS of patients with high TSP was $56 \%$. Unfortunately, the differences were not statistically significant, in contrast to the results of Park et al (23) who reported a shorter cancer-specific survival (CSS) in CRC patients in stage I-III of the high-TSP compared to those in which low-TSP was found. In subsequent studies, the author confirmed that the 5 -year survival of low TSP was $80 \%$ and in the high TSP group in $90 \%$ (4). We also assessed the overall parameters of inflammatory cell infiltrate and TSP by GMS, which did not confirmed statistically significant differences in DFS. Our observations are contrary to the results of Park et al (4). These differences may be due to sample size, nationality of the selected population and the scope of the TNM staging of patients enrolled in the study.

Multivariate analysis showed that the inflammatory cell infiltrate in the invasive front of the primary tumor is an independent prognostic factor in patients with CRC. Richards et al (26) presented that a low grade of local immune 
response, TNM, venous invasion were associated indecently with reduced CSS. On the other hand, Park et al (23) demonstrated that low TSP in stage I to III of patients with CRC is associated with N0 status and those who received adjuvant chemotherapy had reduced CSS. It seems that the inflammatory cell infiltration is a very important part of the tumor, which, along with routinely assessed morphological, may provide additional prognostic factor in patients with CRC.

In conclusion, the degree of inflammatory cell infiltration in the invasive front of the primary tumor and especially TSP of patients with CRC affects significantly the variables that determine disease progression and DFS. Moreover, the routine, histopathological assessment of both parameters in the basis of tissue material stained with H\&E may have potential diagnostic and prognostic values.

\section{References}

1. Kubiak A, Kycler W and Trojanowski M: Epidemiology and prevention of colorectal cancer in Poland. Probl Hig Epidemiol 95: 636-642, 2014

2. Hamilton SR and Aaltonen LA: Tumours of the colon and rectum. In: World Health Organization Classification of Tumours. Pathology and Genetics of Tumours of the Digestive System. IARC Press, Lyon, pp103-104, 2000.

3. Park JH, McMillan DC, Edwards J, Horgan PG and Roxburgh CS: Comparison of the prognostic value of measures of the tumor inflammatory cell infiltrate and tumor-associated stroma in patients with primary operable colorectal cancer. Oncoimmunology 21: e1098801, 2016.

4. Park JH, McMillan DC, Powell AG, Richards CH, Horgan PG, Edwards J and Roxburgh CS: Evaluation of a tumor microenvironment-based prognostic score in primary operable colorectal cancer. Clin Cancer Res 21: 882-888, 2015.

5. Dvorak HF: Tumor stroma, tumor blood vessels, and antiangiogenesis therapy. Cancer J 21: 237-243, 2015.

6. Conti J and Thomas G: The role of tumour stroma in colorectal cancer invasion and metastasis. Cancers (Basel) 3: 2160-2168, 2011.

7. De Wever O, Demetter P, Mareel M and Bracke M: Stromal myofibroblasts are drivers of invasive cancer growth. Int J Cancer 123: 2229-2238, 2008.

8. Crispino P, De Toma G, Ciardi A, Bella A, Rivera M, Cavallaro G, Polistena A, Fornari F, Unim H, Pica R, et al: Role of desmoplasia in recurrence of stage II colorectal cancer within 5 years after surgery and therapeutic implication. Cancer Invest 26: 419-425, 2008

9. Yoong KF, Afford SC, Randhawa S, Hubscher SG and Adams DH: Fas/Fas ligand interaction in human colorectal hepatic metastases: A mechanism of hepatocyte destruction to facilitate local tumor invasion. Am J Pathol 154: 693-703, 1999.

10. Conti JA, Kendall TJ, Bateman A, Armstrong TA, Papa-Adams A, Xu Q, Packham G, Primrose JN, Benyon RC and Iredale JP: The desmoplastic reaction surrounding hepatic colorectal adenocarcinoma metastases aids tumor growth and survival via alphav integrin ligation. Clin Cancer Res 14: 6405-6413, 2008.

11. Cui G, Goll R, Olsen T, Steigen SE, Husebekk A, Vonen B and Florholmen J: Reduced expression of microenvironment Th1 cytokines accompanies adenomas-carcinomas sequence of colorectum. Cancer Immunol Immunother 56: 985-995, 2007.

12. Galon J, Costes A, Sanchez-Cabo F, Kirilovsky A, Mlecnik B, Lagorce-Pagès C, Tosolini M, Camus M, Berger A, Wind P, et al: Type, density, and location of immune cells within human colorectal tumors predict clinical outcome. Science 313 1960-1964, 2006.

13. Mei Z, Liu Y, Liu C, Cui A, Liang Z, Wang G, Peng H, Cui L and $\mathrm{Li} \mathrm{C}$ : Tumour-infiltrating inflammation and prognosis in colorectal cancer: Systematic review and meta-analysis. Br J Cancer 110: 1595-1605, 2014
14. Oken MM, Creech RH, Tormey DC, Horton J, Davis TE, McFadden ET and Carbone PP: Toxicity and response criteria of the Eastern Cooperative Oncology Group'. Am J Clin Oncol 5: 649-655, 1982.

15. Therasse P, Arbuck SG, Eisenhauer EA, Wanders J, Kaplan RS, Rubinstein L, Verweij J, Van Glabbeke M, Van Oosterom AT, Christian MC and Gwyther SG: New guidelines to evaluate the response to treatment in solid tumors. European Organization for Research and Treatment of Cancer, National Cancer Institute of the United States, National Cancer Institute of Canada. J Natl Cancer Inst 92: 205-216, 2000.

16. Lin Q, Wei Y, Ren L, Zhong Y, Qin C, Zheng P, Xu P, Zhu D, $\mathrm{Ji} \mathrm{M}$ and $\mathrm{Xu} \mathrm{J}$ : Tumor deposit is a poor prognostic indicator in patients who underwent simultaneous resection for synchronous colorectal liver metastases. Onco Targets Ther 8: 233-240, 2015.

17. Morodomi T, Isomoto $\mathrm{H}$, Shirouzu K, Kakegawa $\mathrm{K}$ and Irie $\mathrm{K}$ and Morimatsu M: An index for estimating the probability of lymph node metastasis in rectal cancers. Lymph node metastasis and the histopathology of actively invasive regions of cancer. Cancer 63: 539-543, 1989.

18. Richards CH, Flegg KM, Roxburgh CS, Going JJ, Mohammed Z, Horgan PG and McMillan DC: The relationships between cellular components of the peritumoural inflammatory response, clinicopathological characteristics and survival in patients with primary operable colorectal cancer. Br J Cancer 106: 2010-2015, 2012.

19. Väyrynen JP, Sajanti SA, Klintrup K, Mäkelä J, Herzig KH, Karttunen TJ, Tuomisto A and Mäkinen MJ: Characteristics and significance of colorectal cancer associated lymphoid reaction. Int J Cancer 134: 2126-2135, 2014.

20. Ueno H, Jones AM, Wilkinson KH, Jass JR and Talbot IC: Histological categorisation of fibrotic cancer stroma in advanced rectal cancer. Gut 53: 581-586, 2004.

21. Klintrup K, Mäkinen JM, Kauppila S, Väre PO, Melkko J, Tuominen H, Tuppurainen K, Mäkelä J, Karttunen TJ and Mäkinen MJ: Inflammation and prognosis in colorectal cancer. Eur J Cancer 41: 2645-2654, 2005

22. Huijbers A, Tollenaar RA, v Pelt GW, Zeestraten EC, Dutton S, McConkey CC, Domingo E, Smit VT, Midgley R, Warren $\mathrm{BF}$, et al: The proportion of tumor-stroma as a strong prognosticator for stage II and III colon cancer patients: Validation in the VICTOR trial. Ann Oncol 24: 179-185, 2013.

23. Park JH, Richards CH, McMillan DC, Horgan PG and Roxburgh CS: The relationship between tumour stroma percentage, the tumour microenvironment and survival in patients with primary operable colorectal cancer. Ann Oncol 25: 644-651, 2014.

24. Menon AG, Janssen-van Rhijn CM, Morreau H, Putter H, Tollenaar RA, van de Velde CJ, Fleuren GJ and Kuppen PJ: Immune system and prognosis in colorectal cancer: A detailed immunohistochemical analysis. Lab Invest 84: 493-501, 2004.

25. Väyrynen JP, Tuomisto A, Klintrup K, Mäkelä J, Karttunen TJ and Mäkinen MJ: Detailed analysis of inflammatory cell infiltration in colorectal cancer. Br J Cancer 109: 1839-1847, 2013.

26. Richards $\mathrm{CH}$, Roxburgh CS, Anderson JH, McKee RF, Foulis AK, Horgan PG and McMillan DC: Prognostic value of tumour necrosis and host inflammatory responses in colorectal cancer. Br J Surg 99: 287-294, 2012.

27. Nakano O, Sato M, Naito Y, Suzuki K, Orikasa S, Aizawa M, Suzuki Y, Shintaku I, Nagura H and Ohtani H: Proliferative activity of intratumoral CD8(+) T-lymphocytes as a prognostic factor in human renal cell carcinoma: Clinicopathologic demonstration of antitumor immunity. Cancer Res 61: 5132-5136, 2001.

28. Zhang L, Conejo-Garcia JR, Katsaros D, Gimotty PA, Massobrio M, Regnani G, Makrigiannakis A, Gray H, Schlienger K, Liebman MN, et al: Intratumoral T cells, recurrence and survival in epithelial ovarian cancer. N Engl J Med 348: 203-213, 2003.

29. Sato E, Olson SH, Ahn J, Bundy B, Nishikawa H, Qian F, Jungbluth AA, Frosina D, Gnjatic S, Ambrosone C, et al: Intraepithelial $\mathrm{CD} 8^{+}$tumor-infiltrating lymphocytes and a high $\mathrm{CD} 8^{+} /$regulatory $\mathrm{T}$ cell ratio are associated with favorable prognosis in ovarian cancer. Proc Natl Acad Sci USA 102: 18538-18543, 2005. 